\title{
TIMP2 wt Allele
}

National Cancer Institute

\section{Source}

National Cancer Institute. TIMP2 wt Allele. NCI Thesaurus. Code C52120.

Human TIMP2 wild-type allele is located in the vicinity of $17 q 25$ and is approximately $72 \mathrm{~kb}$ in length. This allele, which encodes metalloproteinase inhibitor 2 protein, plays a role in extracellular matrix maintenance. 